\title{
NILAI BUDAYA WALIMAH PERKAWINAN (WALIMATUL 'URUSY) \\ DALAM PEMBERDAYAAN EKONOMI MASYARAKAT (Studi Kasus di Kelurahan Gondorio Ngaliyan Semarang)
}

\author{
Muyassarah \\ Universitas Islam Negeri Walisongo Semarang \\ muyassarab93@yahoo.com
}

\begin{abstract}
This study aims to know the culture walimah marriage (walimatul 'urusy) in Semarang Gondorio economic empowerment. Data collection methods, the methods of documentation, observation, interview and literature search literature. In order to keep the scientific interpretation, taken by way of reflective thinking, meaning pacing between deduction and induction. The findings of this study are: Invitation walimah marriage (walimatul 'urusy) implemented before the ongoing Islamic marriage contract, to ask for their blessing and tablil. The husband and wife donate everything, so that people who have a celebration not a lot of debt or burden. Culture delehi implemented in walimah marriage (walimatul 'urusy), to lighten the load and save. Culture ceting implemented in walimah marriage (walimatul urusy), in order to have a celebration that can provide snacks to guests. Culture walimah marriage in Gondorio able to empower the local economy.
\end{abstract}

Keywords: Culture, Walimah Marriage, Economic Empowerment

\begin{abstract}
Abstrak
Penelitian ini bertujuan mengetahui budaya walimah perkawinan (walimatul 'urusy) dalam pemberdayaan ekonomi masyarakat Gondorio Semarang. Metodepengumpulan data, dengan metode dokumentasi, observasi, wawancara dan penelusuran literatur kepustakaan. Agar interpretasinya tetap ilmiah, ditempub cara berpikir reflektif, maksudnya mondar mandir antara deduksi dan induksi. Temuan dari penelitian ini yakni: Undangan walimah perkawinan (walimatul 'urusy) dilaksanakan sebelum berlangsungnya ijab qabul, untuk meminta doa restu dan tablil. Suami istri (suastri) nyumbang semuanya, agar orang yang mempunyai hajatan tidak banyak butang atau beban. Budaya delehi dilaksanakan dalam walimah perkawinan (walimatul urusy), untuk meringankan beban dan menabung. Budaya ceting dilaksanakan dalam walimah perkawinan (walimatul urusy), agar yang mempunyai hajatan dapat memberikan makanan kecil kepada para tamu. Budaya walimah perkawinan di Gondorio mampu memberdayakan ekonomi masyarakat.
\end{abstract}

Kata Kunci: Budaya, Walimah Perkawinan, Pemberdayaan Ekonomi

Permalink/DOI: http://dx.doi.org/10.18326/infs13.v10i2.539-558 


\section{Pendahuluan}

Dalam dahsatnya gelora modernitas sejalan dengan perkembangan zaman di era globalisasi ini masih ada sekelompok masyarakat yang menjalankan tradisi-tradisi yang masih klasik. Budaya bisa berkembang sejalan dengan perkembangan zaman, maka terjadinya perubahan sosial menyangkut bidang kehidupan yang luas, tidak saja dalam hal tuntutan hidup ekonomi atau komunikasi dan teknologi melainkan juga dalam bidang sosial budaya. Perubahan itu tidak sekedar hanya masyarakat berubah melainkan di balik tendensi yang menuju ke arah positif, juga dampak perubahan kehidupan yang negatif lebih-lebih kehidupan bermasyarakat. Sehubungan dengan hal di atas, tidak dapat dipungkiri pada zaman sekarang ini banyak orang yang senang bermewah-mewah dalam berpakaian, pergaulan bebas (dekadensi moral) dan kurangnya rasa malu dan rasa berdosa dalam melakukan kemaksiatan. (Imam Nawawi, $\mathrm{tt}$, : 18). Oleh karena itu pendidikan masyarakat sangat penting diterapkan pada anak cucu, sehingga dalam menjalankan budayabudaya masyarakat sejalan dengan nilai edukasi dan nilai Islam agar ketentraman hidup dan kedamaian bisa terwujud. Lingkungan masyarakat adalah sebuah kelompok besar yang terdiri dari berbagai tingkatan pengetahuan dan tingkat pemahaman terhadap sebuah tradisi yang berkembang di sekitarnya.

Adat budaya walimatul urusy atau pernikahan antara daerah satu dengan daerah yang lain sering terjadi perbedaan tradisi yang dilaksanakan secara turun temurun. Bahkan di daerah kota Semarang tepatnya desa Gondorio kecamatan Ngalian dalam melaksanakan acara walimah pernikahan malah memerlukan beberapa hari. Malam hari pertama terdapat undangan walimatul urusy yang isinya tahlilan, siang harinya hiburan kebanyakan dangdut, dan malam kedua terdapat pengajian atau jika tidak ada pengajian maka biasanya diisi hiburan melanjutkan hiburan tadi siang misalnya qasidah atau dangdut. Hal ini ada pandangan bahwa jika terdapat orang yang mempunyai hajatan atau walimatul 'urusy, maka tetangga dan masyarakat sekitar banyak mengeluarkan uang untuk menyumbang sehingga terasa boros sehingga perekonomian masyarakat agak terganggu. 
Tetapi di pihak lain, ada yang berpandangan bahwa dengan adanya orang yang mempunyai hajatan walimatul 'urusy itu maka masyarakat dan tetangga bisa menikmati makanan yang telah disediakan menambah gizi, warung atau toko sekitar laku karena banyak tetangga yang membeli beras, gula dan kebutuhan lain untuk disumbangkan, secara tiba tiba mendadak banyak orang yang menjual sesuatu di sekitar rumah yang mempunyai hajatan. Di samping itu orang yang mempunyai hajatan ternyata tidak perlu modal banyak, karena sudah banyak dibantu oleh tetangga yang telah disumbang sebelumnya. Bagi para tetangga juga merasa tidak keberatan, karena di samping sudah merupakan warisan tinggalan nenek moyang, juga bisa diniati menabung bisa merencanakan anggaran masa depan jika mau mengadakan walimatul urusy, karena suatu saat mempunyai hajatan yang sama, sudah tidak susah payah mencari uang atau modal banyak, tetapi sudah mendapat bantuan sumbangan dari orang yang telah disumbang sebelumnya. Dapat dikatakan bahwa dengan adanya acara walimatul 'urusy ini baik yang mempunyai hajatan maupun masyarakat para tetangga dapat memberdayakan perekonomian mereka.

Peneliti tertarik meneliti tentang budaya walimah perkawinan (walimatul 'urusy) di masayarakat Gondorio Semarang, karena ada beberapa hal unik dalam adat budaya walimah perkawinan di Gondorio yang tidak terdapat di daerah lainnya, bahkan seIndonesia-pun jauh berbeda dan banyak keunikan di masyarakat Gondorio Semarang. Oleh karena itu peneliti tergugah untuk mengadakan penelitian tentang budaya walimah perkawinan (walimatul 'urusy) yang dilakukan di Gondorio Semarang dalam meningkatkan pemberdayaan ekonomi masyarakat. Berdasarkan latar belakang di atas maka peneliti berminat untuk mengadakan suatu penelitian dengan judul Nilai Budaya Walimah Perkawinan (walimatul 'urusy) dalam Pemberdayaan Ekonomi Masyarakat (Studi Kasus di Kelurahan Gondorio Ngaliyan Semarang) Tahun 2016.

Untuk memperjelas masalah yang akan diteliti perlu diterangkan mengenai batasan masalah. Dalam pembatasan masalah ini peneliti bedakan menjadi dua yaitu pembatasan ruang lingkup masalah dan ruang lingkup obyek penelitian. Ruang lingkup masalah 
yang akan diteliti pertama adalah budaya walimah perkawinan (walimatul 'urusy) masyarakat Gondorio Semarang, yang kedua korelasi budaya walimah perkawinan (walimatul 'urusy) dalam pemberdayaan ekonomi masyarakat Gondorio Semarang, ketiga adalah keunikan-keunikan budaya walimah perkawinan yang dilestarikan masyarakat Gondorio Semarang. Adapun ruang lingkup obyek penelitian adalah masyarakat Gondorio Ngalian Semarang sebagai responden. Untuk pemilihan sampel ini didasarkan pada pertimbangan bahwa masyarakat Gondorio Semarang dalam melaksanakan budaya walimah perkawinan (walimatul 'urusy) banyak keunikan-keunikan yang dijalankan yang berbeda dengan masyarakat daerah lain di penjuru tanah air Indonesia.

Fokus penelitian ini adalah mengetahui alasan undangan walimah perkawinan (watimatul 'urusy) dilaksanakan sebelum berlangsungnya ijab qabul, keharusan nyumbang saat mendatangi walimah perkawinan (walimatul urusy), budaya delehi dilaksanakan dalam walimah perkawinan (walimatul 'urusy), budaya ceting dilaksanakan dalam walimah perkawinan (walimatul 'urusy) dan budaya walimah perkawinan (walimatul 'urusy) dalam pemberdayaan ekonomi masyarakat.

\section{Adat Budaya}

Adat budaya pada hakekatnya merupakan suatu hal yang paling mendasar dalam kehidupan bermasyarakat, oleh karena itu budaya di dalam kehidupan bermasyarakat sangat kompleks. Ini merupakan modal yang paling utama pada manusia yang termasuk sebagai makhluk sosial. Pengertian budaya di sini adalah cara berpikir dan cara merasa yang menyatakan diri dalam seluruh segi kehidupan kelompok manusia yang membentuk kesatuan sosial. (Gazalba, 1988: 11). Dengan adanya budaya tersebut maka masyarakat menjadi kuat. Jadi manusia sosial yang baik sangat tergantung pada besar kecilnya melestarikan budaya Islami di tengah-tengah kehidupan masyarakat, karena budaya merupakan bagian aktivitas masyarakat yang berhubungan erat dengan sikap, tingkah laku seseorang terhadap budaya perkawinan yang ada di lingkungan masyarakatnya. Adapun pengertian budaya di antaranya adalah: 
kata yang mendapat imbuhan kata awalan ke dan akhiran an yang menjadi kebudayaan. (Chafidh, 2006: 132). Kebudayaan adalah bagaimana sekelompok orang berpikir dan merasakan suatu tradisi yang berlaku di masyarakat tersebut yang akhirnya membentuk menjadi kebiasaan yang turun temurun. Budaya yang peneliti maksudkan adalah tradisi-tradisi yang dilakukan masyarakat Gondorio Semarang tentang walimah perkawinan (walimatul urusy).

Dalam Islam, agama adalah posisi primer, sedangkan budaya adalah sekunder. Adat budaya dapat merupakan ekspresi hidup beragama, sub ordinate terhadap agama, dan tidak sebaliknya. Agama adalah absolut, berlaku untuk setiap ruang dan waktu, adat budaya adalah relative terbatas oleh ruang dan waktu. (Hadi, 1983: 4) Pada dasarnya adat budaya yang muncul dan berkembang itu merupakan produk dari aktifitas kehidupan manusia, termasuk adanya cipta, rasa dan karya manusia. Terdapatnya perbedaan geografis, iklim, dan alam akan memberikan berbagai pengaruh yang memunculkan berbagai ragam dan macam budaya termasuk adat budaya walimah perkawinan (watimatul 'urusy).

Islam dan adat budaya tidak saling mencakup, maksudnya agama Islam bukan bagian dari budaya atau sebaliknya. Karena keduanya berbeda walaupun antara agama Islam dan budaya bisa saja -bahkan harus- saling berhubungan dan bersentuhan dalam wilayah aktifitas manusia. Hasil sentuhan tersebut bisa melahirkan suatu adat budaya yang diwarnai agama Islam.

\section{Walimah}

Islam memberikan konsep mengenai tata cara pernikahan antara lain walimatul 'urusy yakni merupakan pesta atau tasyakuran yang mana hukumnya sunnah, namun ada yang mengatakan wajib dengan alasan sunnah rasul, sebagai seorang muslim perlu menyelenggarakan walimahan walaupun dengan hanya menyembelih seekor kambing. Acara walimahan dilakukan kapan saja artinya bisa dilaksanakan setelah akad nikah atau ditunda berhari-hari berakhirnya pengantin baru. Namun dalam Islam 
dianjurkan lebih baik tiga hari setelah hubungan badan (dukhul). (Tim Baitul Kilmah, 2013: 297). Jadi secara Islam bahwa walimatul 'urusy itu dilaksanakan setelah terjadinya ijab qabul atau akad nikah, namun di Gondorio mengadakan walimatul 'urusy itu justru dilakukan bukan setelah akad nikah tetapi malah sebelum akad nikah.

Walimah adalah perayaan yang dilaksanakan dalam acara tasyakuran pernikahan, dengan mendatangkan undangan para tetangga dan kerabatnya agar calon temanten dikenal dan diketahui oleh para tetangga dan kerabatnya tersebut. Hal ini juga dapat berfungsi untuk lebih mempererat persatuan dan kekeluargaan di antara mereka. Undangan yang hadir merupakan wahana untuk meminta doa restu untuk mempelai agar bisa membentuk keluarga sakinah mawadah wa rahmah. Selain untuk meminta doa restu merupakan wahana silaturahmi untuk bercengkerama dengan saudara dan kerabat yang lama tidak bertemu.

\section{Perkawinan}

Perkawinan atau pernikahan berasal dari kata nikah yang mendapatkan imbuhan awalan per dan akhiran an yang artinya kumpul atau menyatunya dua orang disatukan dalam ikatan akad nikah.yang disebut ijab-qabul yang merupakan pernyataan dua pasangan perempuan dan laki-laki untuk menjalin hubungan suami istri. Dalam istilah lain nikah adalah ikatan suami istri untuk menjalin kehidupan keluarga yang sudah diikat dengan memenuhi syarat dan rukun tertentu. Sejalan dengan anjuran Islam bahwa manusia hidup itu berpasang-pasangan dan menghalalkan pernikahan dan mengharamkan zina. Akad nikah itu merupakan prosesi sederhana yang mana terdiri dari dua kata ijab dan qabul. Ijab artinya pernyataan dari pihak laki-laki dan qabul merupakan jawaban dari pihak perempuan. Dengan dua kata tersebut dapat membuat dua makhluk yang awalnya bujangan/jomblo menjadi pasangan suami istri yang bernilai ibadah jika dilaksanakan dengan niat dan cara yang sesuai dengan nilai-nilai Islam. 
Pernikahan bisa sah jika memenuhi beberapa rukun antara lain ada ijab qabul, ada 2 calon suami istri, wali, dan saksi. (Zaenuddin bin Abdul Aziz, tt.: 86). Di antara rangkaian pernikahan ada yang disebut walimatul 'urusy, yaitu sebuah jamuan makan yang menghadirkan para undangan di sebuah acara pernikahan. (Afna Chafidh, 132). Walimatul 'urusy atau biasa disebut walimah adalah pesta pernikahan yang disunahkan, sebagai pemberitaan kepada khalayak dan ungkapan syukur atas terjadinya pernikahan. Adapun walimahan berasal dari kata walimah yang artinya pesta yakni mengadakan sajian makan dalam rangka memberikan hidangan makanan kepada masyarakat yang diundang untuk memberikan doa restu atas terlaksana hajatnya. (Afna Chafidh, 132). Walimahan mantenan adalah merupakan budaya ketika acara nikah berlangsung atau sesudahnya, bisa juga dilaksanakan sesuai dengan adat dan kebiasaaan yang berlaku dalam masyarakat. (Slamet Abidin, 1999: 149). Walimahan mantenan merupakan ikatan lahir batin anatara pria dan wanita sebagai suami istri dengan tujuan membentuk keluarga yang bahagia dan kekal berdasarkan Tuhan Yang Maha Esa. (UU Perkawinan nomor 1 tahun 1974). Oleh karena itu walimah harus menampakkan syiar kebaikan, sehingga ada nilai ibadah, dakwah dan sosial yang terhimpun di dalamnya. Yang harus diperhatikan, antara lain: jangan mengandung unsur kemaksiatan, jangan berlebihan, bukan untuk gengsi, dan hendaknya dengan mengundang fakir miskin.

Budaya masyarakat agar lebih memberikan manfaat, maka perlu dijiwai dengan nilai Islam. Dalam Islam sudah mengatur bermuamalah, secara individu atau kelompok hendaknya dijiwai nilai spiritual dan akhlak yang meliputi kehidupan manusia dan tingkah laku dengan segala aspek yang melingkupinya. (Mansur, 2011: 5). Oleh karena itu dapat dikatakan bahwa ternyata budaya masyarakat yang mengandung nilai-nilai paedagogik itu mempunyai beberapa fungsi terhadap anggota masyarakat secara positif. Masyarakat dan budaya tidak bisa dipisahkan karena keduanya merupakan suatu jalinan yang erat saling berkait karena budaya tidak akan ada tanpa masyarakat dan tidak ada satu kelompok manusiapun, betapa terasing dan bersahaja hidupnya jika tidak menjalankan budaya yang dijalankan masyarakat di mana mereka hidup. Semua kelompok 
masyarakat pasti memiliki budaya karena manusia merupakan subyek budaya. (Faisal Ismail, 1997: 24-25). Manusia secara qodrati telah diciptakan Allah sebagai makhluk sosial yang sempurna, oleh karenanya ada semacam kewajiban yang inhern dalam diri manusia yakni mengaktualkan keunggulan kualitas tersebut baik segi fisik, mental, intelektual, maupun spiritualnya. Aktualisasi potensi diri sebagai makhluk yang paling superior tersebut adalah merupakan fungsi kodrati manusia, suatu proses insanisasi. Fungsi kodrati yang lain adalah "pengabdian" dalam statusnya sebagai hamba Allah yang berdimensi transendental (ibadah khusus) juga tercermin dalam dimensi harisontal (ibadah umum), kekhalifahan sebagai fungsi kodrati yang lain yakni menjadi wakil Allah dalam mengelola dan mengatur kehidupan dunia agar tercipta aman harmonis dan sejahtera di bawah ridho-Nya. Fungsi yang lain adalah kerisalahan yakni menyampaikan kebenaran agama Islam sebagai pedoman hidup manusia untuk mencapai keselamatan dan kebahagiaan di dunia dan akherat. Dalam ajaran Islam budaya bisa disebut alurf atau kebiasaan-kebiasaan yang dipraktekan oleh sekelompok masyarakat, namun yang dianjurkan kebiasaan atau adat istiadat yang diperbolehkan dalam Islam adalah kebiasaan yang baik (hasanah) sedangkan yang jelek (sayyiah) hendaknya dijauhkan dari kebiasaan masyarakat. Oleh karena itu budaya dengan Islam sangat berkaitan karena budaya tradisi merupakan bagian aktifitas masyarakat yang mana dalam penelitian ini adalah aktifitas walimahan perkawinan (walimatul'urusy) yang dipraktekkan turun temurun.

Akad nikah bukanlah merupakan perjanjian dua insan, namun akad nikah juga perjanjian antara makhluk Allah dengan al-Khaliq. Saat pelaksanaan dua tangan berjabat tangan antara wali nikah dengan mempelai laki-laki untuk mengucapkan akad nikah/ ijab qabul, maka di atasnya ada tangan allah SWT. Dalam Islam memberikan konsep mengenai tata cara pernikahan antara lain: (Tim Baitul Kilmah, 2013: 296). Mengenal pasangan hidup, melihat calon pasangan hidup, peminangan, akad nikah, walimatul 'urusy. Hubungan nikah merupakan ikatan di antara dua insan walaupun dua keluarga yang dijadikan satu walaupun banyak perbedaan baik cara berpikir, latar belakang pendidikan, latar belakang keluarga, fisik maupun latar belakang lingkungan dan lain-lain. Pernikahan 
yang sah merupakan suatu ikatan yang sangat mulia yang mana dua insan yang membawa banyak perbedaan dapat hidup bersama yang dilakukan prosesinya secara islami dan menurut negara yang disaksikan oleh kerabat dari dua keluarga dan masyarakat sekitarnya. Para hadirin yang menyaksikan acara pernikahan merupakan orang yang diminta doa untuk dua pasangan agar menjadi keluarga sakinab mawadah wa rahmah. Oleh karena itu kesaksian masyarakat dan kerabat dua keluarga mempelai juga merupakan saksi agar kelak tidak ada fitnah di kemudian hari. Orang yang hadir bisa menjadi saksi dan bisa menjelaskan bahwa pasangan tersebut sudah resmi dan sah bergaul sebagaimana hubungan suami istri.

\section{Metode Penelitian}

Jenis dan Desain Penelitian.

Penelitian ini merupakan penelitian lapangan (field research), dan penelitian ini bersifat kualitatif deskriptif, yaitu peneliti menjajaki, menguraikan, dan menerangkan adat walimatul 'urusy dalam memberdayakan masyarakat. Peneliti mengambil kelurahan Gondorio Ngalian Semarang. Karena kelurahan Gondorio ini mempunyai tradisi walimah yang unik dibanding dengan daerah lainnya.

Teknik pengumpulan data dan metode. Untuk memperoleh data, dipergunakan cara berikut ini: dokumen, observasi, wawancara dan penelusuran literatur kepustakaan. Untuk memahami gejala struktural dan kultural maka digunakan pendekatan sosio kultural. Studi kritis juga dilakukan untuk mengkritisi sejauhmana budaya walimah temanten memberdayakan ekonomi masyarakat. Melihat pada keterkaitannya dengan penafsiran bukti, maka mempunyai hubungan yang erat dengan metode deskriptif. Metode yang digunakan dalam penyusunan penelitian ini adalah sebagai berikut: Metode Pengumpulan Data. Untuk membahas tentang kerangka teori dalam penelitian ini, digunakan buku-buku sebagai bahan acuan yang berupa teori-teori yang terkait dalam penelitian ini.

Adapun untuk mengetahui keadaan budaya masyarakat desa Gondorio Semarang, metode yang peneliti gunakan dalam 
pengumpulan data-data terutama budaya walimah perkawinan (walimatul 'urusy) adalah sebagai berikut: Metode observasi yaitu metode pengamatan dan pencatatan secara sistematik fenomenafenomena yang diselidiki. (Sutrisno Hadi, 1977: 159). Dalam pelaksanaannya peneliti menggunakan metode observasi langsung yakni dengan mendatangi masyarakat yang menjalankan budaya walimah perkawinan (walimatul 'urusy) di kelurahan Gondorio Semarang. Metode interview yakni metode untuk mendapatkan orang dengan mengadakan hubungan secara langsung dengan informen. (Bimo Walgito, 1980: 68). Metode interview ini peneliti mengadakan wawancara secara langsung kepada informan ketika peneliti mendapat undangan laden dan undangan walimatul 'urusy malam harinya kepada orang yang berada dekat peneliti. Laden adalah membantu pada saat acara mantenan H-3 biasanya lakilaki bekerja mengupas kelapa dengan jumlah yang sangat banyak umumnya 5-7 sak dalam ukuran besar dan yang perempuan marut kelapanya kemudian diambil santannya, santan dibuat makanan yang disebut jenang dan wajik dengan memakai wajan wojo ukuran besar biasanya 4-5 jadi, laki-lakilah yang membuat jajanan jenang dan wajik tersebut. (Endang Saifuddin Anshari, 1987: 61). Peneliti juga mengadakan wawancara dengan tokoh-tokoh masyarakat setempat misalnya kyai setempat, tokoh masyarakat maupun masyarakat Gondorio Semarang. Peneliti juga menggunakan metode dokumentasi untuk memperkuat data yang diperoleh. Dalam pengambilan subyek penelitian peneliti mengambil masyarakat kelurahan Gondorio Semarang.

\section{Teknik analisis data}

Dalam penelitian ini digunakan pula metode analisis terhadap data-data yang telah terkumpul melalui dokumen, observasi, interview atau wawancara untuk memperoleh perspektif yang jelas. Selanjutnya agar interpretasinya tetap ilmiah, maka ditempuh cara berpikir reflektif, maksudnya mondar mandir antara deduksi dan induksi. Untuk menganalisis data-data yang telah terkumpul maka peneliti menggunakan metode analisis data kualitatif yakni suatu analisis data yang terkumpul dan data itu bersifat monografis/ 
terbatas, dalam rangka penelitian kualitatif yang umumnya terdiri dari responden dan data-data dengan jumlah agak terbatas. (Jacob Vredenbregt, 1981: 127). Analisis data dilakukan dengan melalui kaca mata teori yang dikembangkan terutama berkaitan dengan teori budaya dan pernikahan.

\section{Hasil Penelitian}

Gondorio merupakan sebuah kelurahan di wilayah Kecamatan Ngalian, Kota Semarang, Provinsi Jawa Tengah. Adapun jumlah RT, RW, dasa wisma dapat dilihat dalam tabel 1. Adapun jumlah penduduk menurut kelompok umur dapat dilihat dalam tabel 2, tingkat pendidikan dalam tabel 3, mata pencaharian dalam tabel 4, pemeluk agama dapat dilihat dalam tabel 5.(Dokumentasi di kantor kelurahan Gondorio Ngaliyan, Semarang).

\section{Tabel I}

Jumlah RT, RW, DASA WISMA

\begin{tabular}{ccc}
\hline RT & RW & DASA WISMA \\
\hline 61 & 11 & 80 \\
\hline Sumber: Monografi Kelurahan Gondorio
\end{tabular}

Tabel 2

Jumlah Penduduk Menurut Kelompok Umur

\begin{tabular}{ccc}
\hline Usia & Laki-Laki & Perempuan \\
\hline $0-4$ & 413 & 399 \\
$5-9$ & 348 & 288 \\
$10-14$ & 213 & 204 \\
$15-19$ & 145 & 167 \\
$20-24$ & 168 & 207 \\
$25-29$ & 302 & 415 \\
$30-34$ & 414 & 405
\end{tabular}




\begin{tabular}{ccc}
$35-39$ & 370 & 315 \\
$40-44$ & 280 & 198 \\
$45-49$ & 154 & 128 \\
$50-54$ & 89 & 106 \\
$55-59$ & 58 & 51 \\
$60-64$ & 26 & 29 \\
$65-69$ & 16 & 35 \\
$70-74$ & 31 & 46 \\
$75+$ & 23 & 26 \\
\hline Sumber: Monografi Kelurahan Gondorio \\
\multicolumn{4}{c}{ Tabel 3 }
\end{tabular}

\section{Jumlah Penduduk Menurut Tingkat Pendidikan}

\begin{tabular}{cccccccc}
\hline $\begin{array}{c}\text { Tidak } \\
\text { Sekolah }\end{array}$ & $\begin{array}{c}\text { Belum } \\
\text { Tamat } \\
\text { SD }\end{array}$ & $\begin{array}{c}\text { Tidak } \\
\text { Tamat } \\
\text { SD }\end{array}$ & SD & SLTP & SLTA & D.III & PT/S.I \\
\hline 526 & 760 & 408 & 856 & 811 & 1078 & 275 & 230 \\
\hline \multicolumn{7}{c}{ Sumber: Monografi Kelurahan Gondorio } \\
\hline
\end{tabular}

Tabel 4

Jumlah Penduduk Menurut Mata Pencaharian

\begin{tabular}{ccccccccc}
\hline \multirow{2}{*}{ Petani } & $\begin{array}{c}\text { Peng- } \\
\text { usaha }\end{array}$ & $\begin{array}{c}\text { Buruh } \\
\text { Industri }\end{array}$ & $\begin{array}{c}\text { Buruh } \\
\text { Bangunan }\end{array}$ & Pedagang & Angkutan & PNS/ & Jasa/ \\
& & & & ABRI & Pensiunan & Lain \\
$475+109$ & 7 & 667 & 44 & 170 & 94 & 164 & 85 & 31 \\
\hline
\end{tabular}

Sumber: Monografi Kelurahan Gondorio 


\section{Tabel 5}

Jumlah Penduduk Menurut Pemeluk Agama

\begin{tabular}{ccccc}
\hline Islam & $\begin{array}{l}\text { Kristen } \\
\text { Katolik }\end{array}$ & $\begin{array}{c}\text { Kristen } \\
\text { Protestan }\end{array}$ & Hindu & Budha \\
\hline 4902 & 105 & 64 & - & - \\
\hline \multicolumn{5}{c}{ Sumber: Monografi Kelurahan Gondorio }
\end{tabular}

\section{PelaksanaanWali@Matul 'Urusy Sebelum Ijab Qabul}

Manusia dengan akal budinya mampu menciptakan budaya perkawinan yang Islami, manusia dengan akal budinya mampu mengubah natur menjadi kultur yang baik, manusia tidak hanya semata-mata terbenam di tengah-tengah masyarakat materialistik hedonistik akan tetapi manusia wajib mengubah budaya agar bernilai positif di hadapan Allah dan manusia. Budaya mantenan atau acara walimah perkawinan (walimatul urusy) di Gondorio Semarang mayoritas dilaksanakan sebelum berlangsungnya akad nikah. Acaranya diadakan dua hari dua malam, hari pertama mempersiapkan panggung yang besar tanda jika mantenan akan dilaksanakan dan panggung yang besar itu dipersiapkan untuk tempat kyai jika mengundang pengajian dan untuk artis yang manggung jika mengundang atau nanggap hiburan (bisa rebana, qasidah, solo orgen bahkan dangdut), sehingga temanten berdua malahan tidak berada di panggung itu.

Malam pertama mendatangkan banyak orang melalui undangan yang tertulis "walimatul 'urusy" tapi yang unik isinya tahlil. Adapun undangan untuk walimah perkawinan (walimatul 'urusy) hampir semuanya terjadi pada malam hari, tidak pernah dilaksanakan pada siang hari, alasannya menurut beberapa orang yang sempat ditanya oleh peneliti mengatakan bahwa jika siang hari banyak yang berkerja sehingga tidak bisa datang.. Tetapi jika melihat daerah lain, semua manusia juga bekerja, yang bekerja bukan hanya orang Gondorio Semarang, tetapi daerah yang lain kok bisa melaksanakan walimatul 'urusy di waktu siang hari. Adapun setelah walimatul 'urusy yang isinya tahlil itu selesai, diumumkan 
besok malam berikutnya ada pengajian dalam rangka walimatul 'urusy, jadi tidak ada undangan tertulis lagi untuk besok malam hari. Pada malam hari kedua tepatnya setelah pengajian itu selesai maka orang menyerahkan uang (nyumbang) dengan antre kepada orang tua temanten yakni bapaknya yang berdiri atau duduk biasanya di depan pintu rumah, sedangkan ibunya yang menghampiri para tamu undangan perempuan yang datang nyumbang sambil dengarkan santapan pengajian, sehingga para tamu undangan antre satu per satu untuk memberikan amplop yang berisi uang sumbangan tersebut, tapi anehnya yang disumbang yakni orang tua temanten bertempat tidak berada di tempat keluarnya para tamu, tetapi malahan di depan pintu rumah, padahal para tamu banyak berada di halaman rumah. Paginya pada saat akad nikah, anehnya pada saat akad nikah terkesan kurang sakral karena yang hadir hanya petugas pencatat nikah dari pegawai KUA, kedua orang tua ditambah kerabat dari laki-laki dan perempuan bahkan peneliti sering menemukan pihak ibu dari mempelai perempuan tidak ikut menyaksikan akad nikah apalagi tetangga sekitar rumah tidak ada yang ramai-ramai menyaksikan akad nikahnya jika dilaksanakan di rumah. Kemudian setelah selesai ditandai dengan musik-musik melalui soun system dengan pengeras jumbo agar daerah tetangga dapat mendengar sebagai tanda ada orang yang punya gawe kemudian ibu-ibu sekitar tetangga daerah berbondong-bondong datang dengan istilah nyumbang,

Kemudian malam kedua dari serangkaian tsyakuran temanten itu ada acara pengajian. Namun anehnya pada malam pertama dilaksanakannya walimah perkawinan (walimatul 'urusy) yang tentu belum adanya akad nikah, tidak terlihat atau tidak ada kedua mempelai atau kedua temanten dalam acara tersebut. Pada waktu ada pengajian yakni malam kedua yang tentu sudah terlaksananya akad nikah, waktu pengajian itu juga tidak terdapat atau tidak tampak temanten atau mempelai berdua, padahal kedua momentum itu tujuannya kedua mempelai atau temanten untuk minta doa restu kepada tamu undangan yang hadir, tetapi ternyata setelah pengajian selesai, maka tradisi di desa tersebut para tamu undangan berpamitan satu persatu kepada tuan rumah biasanya ayah dan ibunya, sambil nyumbang yakni anehnya yang menerima 
uang juga bukan temantennya tetapi orang tuanya, dan anehnya kedua temanten tidak tampak walau dalam waktu sebentarpun, sehingga praktis tidak menerima langsung doa restu para tamu undangan semuanya.

Dari segi hukum Islam, bahwa yang namanya walimah perkawinan (walimatul urusy) adalah perayaan temanten, jadi walimah menurut Islam adalah setelah terjadinya akad nikah atau ijab qabul secara resmi. Namun kenyataan di lapangan, budaya walimah perkawinan (walimatul 'urusy) yang ada di Gondorio Semarang adalah justru sebelum terjadinya akad nikah, jadi malamnya ada undangan tertulis walimatul 'urusy Setelah malam itu berlangsung, paginya atau siangnya, atau hari berikutnya baru terjadinya akad nikah. Bersamaan dalam acara walimatul 'urusy di malam tersebut biasanya disampaikan oleh pembawa acara bahwa acara walimatul 'urusy ini juga terdapat walimatul khotmil qur'an, dan walimatul aqiqah walaupun orang kaya sekalipun, padahal aqiqah itu dalam Islam dianjurkan hari ke tujuh setelah kelahiran.

\section{Tradisi Nyumbang Dalam Walimatul 'Urusy}

Adapun yang nyumbang, menurut tradisi di Gondorio Semarang tersebut semuanya yang hadir, artinya suami istri (suastri) yang menghadiri undangan walimaul urusy, semuanya kedua-duanya juga harus nyumbang. Jika yang nyumbang hanya salah satu saja misalnya suami saja atau istri saja seperti di daerah selain Gondorio Semarang, maka ada suara yang tidak mengenakkan di telinga bagi yang mendengarnyaKarena memang sudah tradisi di daerah tersebut yakni semuanya laki-laki maupun perempuan, ayah maupun ibu semuanya nyumbang, tidak seperti di daerah lain. Jika di daerah lain yang masih masuk wilayah negara kesatuan republik Indonesia umumnya yang nyumbang hanya salah satu saja, bahkan sampai menghadiri walimatul 'urusy di gedung mewah yang makanannya lengkap dan mewahpun jika yang hadir suami istri bahkan anak semua diajak, maka cukup yang nyumbang hanya salah satu saja sudah cukup. 


\section{Budaya Delehi dalam Walīmatul 'Urusy}

Sebelum hari H-nya kira-kira kurang seminggu sampai tiga hari sebelum walimatul 'urusy, ada tradisi delebi. Delebi adalah tetangga datang ke rumah yang punya hajat membawa sesuatu dalam ukuran banyak misalnya sesorang membawa satu sak beras minim $25 \mathrm{~kg}$, ada yang membawa kelapa 50 buah, telur satu krat, minyak goreng $10 \mathrm{~kg}$, gula, krecek krupuk dan lain-lain, bahkan semakin tahun bertambah dengan alasan bahwa harga dulu dengan harga sekarang berbeda, maka membawanya akan ditambahi. barang yang diminta ketika sang punya gawe datang ke rumah tetangga dalam rangka memberi tahu bahwa dia punya gawe tanggal yang telah ditentukan agar si tetangga ini membantu matiki klopo atau mengelupas kelapa, memasak, istilah di Gondorio Semarang "rewang", kemudian minta sesuatu yang dibutuhkan untuk kepentingan hari H. Saat barang sumbangan diterima dicatat oleh yang punya gawe, dan anehnya anak cucunya nanti yang gantian memberikan sesuatu barang (nyarutang) sama dengan apa yang dibawa tadi. (Jika pemberi (yang ndelehi) di waktu yang akan datang juga mempunyai hajat walimah perkawinan (walimatul urusy) maka juga mengharap pemberian orang yang pernah diberi (didelehi), jadi prakteknya seperti arisan. Dengan demikian dengan sistem tersebut diharapkan semua orang Gondorio Semarang yang kaya maupun yang miskin semua bisa melaksanakan acara walimah perkawinan (walimatul 'urusy) dengan mewah semua. Oleh karena itu jika ada orang Gondorio Semarang mempunyai hajat menikahkan anaknya maka tidak puas (tidak marem) jika tidak mengadakan acara walimah perkawinan (walimatul 'urusy) dengan mewah bahkan setiap ada walimah perkawinan (walimatul 'urusy) pasti membuat panggung yang besar yang digunakan untuk sang kyai yang memimpin tahlil atau mengisi pengajian atau artis yang menghibur para tamu undangan, tetapi anehnya kedua temanten malah tidak berada di panggung tersebut.

\section{Budaya ceting dalam Walìmatul'Urusy}

Ibu-ibu yang berdandan cantik-cantik dengan suka cita tanpa merasa malu menggendong ceting yang berisi kurang lebih 10 roti atau snak makanan anak-anak misalnya ciki-ciki bahkan kadang 
kerupuk bungkusan kemudian ada yang menerima dari wakil tuan rumah. (Pengamatan dan observasi peneliti pada waktu nyumbang bersama dengan para tetangga pada tanggal 29 September 2016 di rumahnya Bapak Suyadi). Para tamu menikmati hidangan kemudian mengambil ceting yang dibawa tadi yang sudah diisi orang yang diberi tugas oleh yang punya hajat kurang lebih 3 jenis makanan anak-anak dan ditambah berkat, yang isinya dalam berkat tersebut terdiri atas makanan nasi, telur atau daging atau gerih atau ikan asing. Berkat di Gondorio adalah ceting atom yang berisi nasi di atas nasi ada lauk mie, oseng-oseng buncis wortel, gorengan ikan kering asin (gereh asin) dan telur rebus, atasnya ditutup kemudian diberi irisan jenang dan jajan dengan dibungkus daun pisang yang komposisi bahannya dari gandum dan gula. Kemudian menghampiri tuan rumah dengan salam tempel amplop berisi uang sumbangan atau nyumbang, jadi para tamu atau ibu-ibu yang nyumbang dengan membawa amplop berisi uang saat berpamitan dengan salam tempel kemudian dari pihak tuan rumah yang punya hajat ada yang memberikan ceting berkat. (Pengalaman peneliti pada waktu nyumbang di rumahnhya Bapak Kuncoro Gondorio pada tanggal 4 Pebruari 2016).

\section{Walīmatul 'Urusy dan pemberdayaan ekonomi}

Budaya walimahan Gondorio Semarang dapat dilestarikan dan diberdayakan karena semua masyarakat Gondorio dapat melakukan hajatan walimahan baik pernikahan maupun khitanan dari tingkat keluarga ekonominya rendah sampai keluarga ekonomi yang mampu. Dengan budaya walimahan Gondorio dapat meningkatkan taraf hidup secara ekonomi lebih baik, terbukti setiap selesainya acara walimahan orang yang baru saja punya hajat tersebut dapat melunasi utang-utangnya kemudian saldonya atau kelebihannya dapat dibelikan sepeda motor untuk digunakan ojek, digunakan untuk membeli obat atau bibit dan pupuk untuk tanaman padi di sawah, atau digunakan membangun warung, digunakan untuk tambahan modal dalam berdagang karena warga Gondorio banyak yang mata pencahariannya sebagai pedagang kecil, atau pengembangan bisnisnya. Budaya walimahan Gondorio mempunyai 
dampak dapat menimbulkan berputarnya roda perekonomian di sekitar Gondorio Semarang.

Budaya walimahan Gondorio merupakan kegiatan seperti arisan yakni gantian bagi yang melaksanakan hajatan walimahan, maka saatnya mereka menerima delehan yang pernah di berikan tetangganya saat walimahan. Sehingga wajar saat menerima delehan harus dicatat barang apa yang dibawa dan dari siapa agar yang menerima punya catatan dengan tujuan suatu saat orang yang member delehi suatu saat mengadakan walimahan dapat juga menerima apa yang diberikannya dan orang yang memberikan delehi terus setiap ada walimahan walaupun belum pernah mengadakan hajatan walimahan, maka saat mereka punya hajatan walimahan, maka banyak menerima delehan tetangga dan mereka hanya sedikit modal yang dibutuhkan hajatan walimahan karena sudah banyak menabung barang di tempat orang lain. Oleh karena itu mereka yang banyak menabung barang di tetangganya semakin sedikit barang yang dibeli saat mereka hajatan walimahan yang disebut menanam sebanyak-banyak maka suatu saat akan menikmatinya.

Catatan delehan tersebut bertujuan untuk mengetahui utang barang apa saja dan kepada siapa agar tidak salah delebi pada orang lain. Dan anehnya ternyata catatan tersebut diwariskan pada anak turunnya jika orang tuanya meninggal dunia. Artinya catatan tersebut merupakan catatan utang arisan yang harus diteruskan pada anaknya, sehingga budaya tersebut turun temurun tidak bisa dihapuskan, terbukti dulu budaya delebi jumlah barangnya sedikit misalnya gula/beras $5 \mathrm{~kg}$, namun lambat laun jumlah barang delehi semakin bertambah banyak misalnya sekarang minimal beras $25 \mathrm{~kg}$ kadang ditambah lainnya. Sehingga bagi yang nabung justru delebi ditambah banyak agar saat panen dapat hasil yang banyak.

Bagi orang yang delehi barang/nabung barang dicatat dengan tujuan merencanakan menabung barang yang dibutuhkan kelak saat akan hajatan walimahan agar saat punya hajat tidak banyak barang yang dibeli atau tidak mubazir. Tujuan tersebut meringankan si punya hajat agar tidak perlu menjual barang berharga demi acaranya cukup dengan system budaya walimahan tersebut. Budaya walimahan tersebut dapat dikatakan mampu memberdayakan ekonomi 
masyarakat baik keluarga yang ekonomi rendah maupun ekonomi yang kuat atau kaya, semua dapat meningkatkan perekonomiannya bahkan dapat meningkatkan pendapatan karena saldo dari hajatan dapat digunakan untuk tambahan modal berdagang dan lainnya.

\section{Kesimpulan}

Undangan walimah perkawinan (walimatul 'urusy) dilaksanakan sebelum berlangsungnya ijab qabul dalam masyarakat Gondorio Semarang. Hal ini dimaksudkan untuk tahlil, meminta doa restu tokoh agama, masyarakat, tetangga dan semua orang yang hadir agar pelaksanaan perkawinan dapat berjalan dengan lancar. Di samping itu tahlil untuk mendoakan para ahli kubur atau leluhur agar diampuni Allah SWT. Suastri harus nyumbang semuanya saat mendatangi walimah perkawinan (walimatul 'urusy) dalam masyarakat Gondorio Semarang. Hal ini dimaksudkan agar orang yang mempunyai hajatan tersebut tidak banyak hutang, karena sumbangan yang ditrerima akan lebih banyak bila dibandingkan dengan yang menyumbang hanya satu orang, suami atau istri saja. Budaya delehi dilaksanakan dalam walimah perkawinan (walimatul 'urusy) dalam masyarakat Gondorio Semarang. Hal ini dimaksudkan untuk meringankan beban yang mempunyai hajatan, tetapi juga dimaksudkan untuk menabung, karena suatu saat jika mengadakan walimah, maka tinggal menghitung delehan yang sudah diberikan kepada orang lain tersebut. Karena delehan yang telah diberikan itu tentu akan dikembalikan pada saat mempunyai hajatan mengadakan walimah. Budaya ceting dilaksanakan dalam walimah perkawinan (walimatul 'urusy) dalam masyarakat Gondorio Semarang. Ceting biasanya diisi makanan kecil, misalnya roti untuk diberikan kepada orang yang punya hajatan, hal ini dimaksudkan agar yang mempunyai hajatan dapat memberikan makanan kecil kepada para tamu. Setelah pulang, maka ceting tadi diisi makanan yang berbeda dengan yang dibawa tadi, hal ini juga akan bisa dimakan oleh keluarga yang membawa ceting tersebut, sehingga mampu meningkatkan gizi bagi para keluarga dan tetangga yang membawa ceting tersebut. Budaya walimah perkawinan (walimatul urusy) dalam pemberdayaan ekonomi masyarakat Gondorio Semarang. Secara umum dapat 
dikatakan budaya walimah perkawinan model Gondorio Ngalian Semarang mampu meningkatkan dan memberdayakan ekonomi masyarakat, baik bagi orang yang mempunyai hajatan maupun bagi para tetangga dan masyarakat sekitar. Bahkan dalam setiap ada acara walimahan di Gondorio, banyak orang yang berjualan makanan, pakaian, dan alat rumah tangga yang lain, tentu hal ini juga mampu memberdayakan dan meningkatkan ekonomi masyarakat.

\section{Daftar Pustaka}

Abidin, Slamet, 1999. Fiqih Munakahat, Pustaka Setia, Bandung.

Anshari, Endang Saifuddin, 1987. Ilmu Filsafat Dan Agama, Bina ilmu, Surabaya,

Aziz, Zaenuddin bin Abdul, Irsyadul Ibad, Toha Putera, Semarang, tt.

Chafidh, Afna, 2006. Tradisi Islam, Khalista, Surabaya

Gazalba, Sidi, 1988. Islam dan Kesenian, Pustaka al Husna, Jakarta. Junaedi, Dedy, 2005. Bimbingan Perkawinan, Akapress, Jakarta,.

Hadi, Sutrisno, 1983 Metodologi Research, jilid 1, Yogyakarta, Fakultas psikologi UGM.

Hadi, Sutrisno, 1977. Metodologi Research Jilid 1l, Yogyakarta, Fakultas Psikologi UGM.

Ismail, Faisal, 1997. Paradigma Kebudayaan Islam ,Titian Illahi Press, Yogyakarta.

Mansur, 2011. Filsafat Pendidikan Islam, Trustmedia, Yogyakarta.

Mansur, 2015. Sejarah Peradaban Islam, Rasail, Semarang.

Mubarok, Mufti, 2008. Ensiklopedi Walimah, Java Pustaka, Surabaya

Nawawi, Imam, Uqudulijain, al-Ma'arif, Bandung, tt

Tim Baitul Kilmah, 2013. Ensiklopedia Pengetahuan Al-Qur'an dan Hadits, Kamil Pustaka, Jakarta,

UU Perkawinan nomor 1 tahun 1974 pasal 1

Vredenbregt, Jacob, 1981. Metode dan Tehnik Penelitian Masyarakat, Gramedia, Jakarta,

Walgito, Bimo, Bimbingan dan Penyuluhan Sekolah, Yogyakarta, Fakultas Psikologi UGM, 1980 